Research Report No. 18/2007

\title{
Takeover Regulation: Through the Regulatory Looking Glass
}

Blanaid Clarke

Follow this and additional works at: http://digitalcommons.osgoode.yorku.ca/clpe

\section{Recommended Citation}

Clarke, Blanaid, "Takeover Regulation: Through the Regulatory Looking Glass" (2007). Comparative Research in Law \& Political Economy. Research Paper No. 18/2007.

http://digitalcommons.osgoode.yorku.ca/clpe/235 


\section{Comparative Research in Law \& Political Economy}

\section{Blanaid Clarke}

Takeover Regulation: Through the Regulatory Looking Glass

EDTORS: Peer Zumbansen (Osgoode Hall Law School, Toronto, Director, Comparative Research in Law and Political Economy, York University), J ohn W. Cioffi (University of California at Riverside), Lindsay Krauss (Osgoode Hall Law School, Toronto, Production Editor) 

CLPE Research Paper 18/2007

Vol. 03 No.05 (2007)

\title{
Special Symposium Issue: \\ EU Governance
}

ProceEdingS FROM THE $10^{\text {TH }}$ IRISH EU LAW ForUM, UNIVERSITY COLLEGE

DUBLIN, 19 JANUARY 2007

\section{Blanaid Clarke}

\section{TAKEOVER REgUlation: THROUgH THE REgUlAtORY LOOKING GLASS}

\begin{abstract}
It is too early to make a complete judgment on the effectiveness of Directive 2004/25/EC on Takeover Bids as a regulatory mechanism. Such a decision would involve determining whether the Directive: achieves its goals, secures high levels of compliance from Member States and market participants and is democratically accountable. However, this paper places the Directive under a regulatory microscope in order to reflect upon some of its potential strengths and failings in respect of these criteria. A central regulatory problem for European legislators involved determining the optimal balance between harmonization and diversity. In an attempt to reach agreement between Member States, a framework Directive was agreed laying down minimum standards for takeover regulation and a number of key provisions were made optional. On the one hand, it is argued that even this "light regulatory touch" may have jeopardised the existing efficient self-regulatory regime which operates in the UK, the largest European takeover market. On the other hand, by allowing Member States a significant degree of discretion in implementing the Directive, problems of interpretation and classification arise (is the Directive a company law directive or a capital markets directive?), regulatory gaps may be identified, national differences emerge and the achievement of the Directive's goal of facilitating takeovers and yielding a level playing field may be thwarted. In respect of the latter, the paper focuses on the restrictions on frustrating action and the breakthrough rule. Finally, the paper seeks to determine whether, in this context, competition
\end{abstract}


is preferable to harmonisation. It was hoped that by setting down benchmarks the Directive might "put a floor to the race to the bottom." Unfortunately, it is argued that the picture post-implementation does not support this contention.

Keywords: takeovers, EU Directive 2004/25/EC, defensive actions, market for corporate control, breakthrough rule, corporate governance

JEL classification: G34, K22, K33

Author Contact: Blanaid Clarke

University College Dublin School of Law

Roebuck Castle, Belfield, Dublin 4, Ireland

Email: blanaid.clarke@ucd.ie 




\title{
TAKEOVER REGULATION: THROUGH THE REGULATORY LOOKING GLASS
}

\author{
Blanaid Clarke*
}

\section{INTRODUCTION}

As the Action Plan on Modernising Company Law and Enhancing Corporate Governance in the European Union (2003) makes clear, the EU has sought to develop company and securities law as vital pillars of an overall attempt to improve Europe's international competitiveness. ${ }^{1}$ An important part of this is the creation of an integrated capital market in the EU. The regulation of takeover bids was deemed to be a key element of such an integrated market. ${ }^{2}$ This paper will focus on Directive 2004/25/EC on Takeover Bids ${ }^{3}$ and will seek to examine it under the regulatory microscope. It is too early to make a complete judgment about the Directive's effectiveness as a regulatory mechanism as this would involve determining whether it achieves its goals, secures high levels of compliance from Member States and market participants and is democratically accountable to the extent that its provisions affect the

\footnotetext{
* Law School, University College Dublin.

${ }^{1}$ Commission Communication. Modernising Company Law and Enhancing Corporate Governance in the European Union - A Plan to Move Forward, COM/2003/0284 final.

${ }^{2}$ Report of the High Level Group of Company Law Experts on Issues Related to Takeover Bids, p.18.

3 This is the primary form of regulation of takeovers at EU level although clearly each of the Market Abuse, Prospectus and Transparency Directives will have implications for the regulation of takeovers.
} 
public interest. ${ }^{4}$ It is however possible to reflect upon some of its potential strengths and failings in respect of these criteria.

A number of factors must be identified at the outset which affect the shape of European takeover regulation. Firstly, each takeover is different because each company is different. Secondly, each market is different in terms of ownership patterns, structure and stage of development of the securities market, availability of finance, importance and role of the banking sector, socio-economic influences and political cultures. Thirdly, the regulation of takeovers falls within the remit of different types of bodies in different Member States each with their own particular structures, agendas, experiences and powers. Finally, takeover law in itself is not a coherent body of law in the way that one might describe constitutional or tort law. It has lots of different areas feeding into it such as company law, securities law, contract law and employment law. From a regulatory perspective thus it might be said to be more permeable, more open to external change than other areas of private law. ${ }^{5}$ On the other hand, these differences have led to diverse treatment of takeovers in different Member States. A central regulatory problem thus is to determine the optimal balance between harmonization and diversity.

In the 1970s, a view emerged in Europe that since takeovers had an overall positive economic effect, harmonised European legislation was required to facilitate takeovers and to provide a level playing field for takeover bids. Despite the introduction in 1985 of a White Paper on Completing the Internal Market which announced an intention to propose a directive on the approximation of Member States' regulations governing takeovers, almost 20 years passed before a directive was actually adopted. During this time the Commission put forward one proposal after another, all of which failed to yield a consensus. The first proposal in 1989 involved a very detailed set of rules to be complied with by Member States. The second proposal in 1996 took the form of a framework directive setting

\footnotetext{
${ }^{4}$ Regulating Law, Parker C, Scott C, Lacey N, Braithwaite J (eds, Oxford, 2004) p.13.

${ }^{5}$ A similar argument was made by Dewar in relation to family law at p.82 of Regulating Law, Parker C, Scott C, Lacey N, Braithwaite J (eds, Oxford, 2004).
} 
out general principles governing takeovers bids but allowing Member States and competent authorities greater scope to deal with the detailed implementation of those principles. Still the process was beset with disagreement about the viability of self-regulatory supervisory authorities, the necessity of mandatory general bids, the treatment of employees during a bid and the possibility of defensive actions. In 2001, the Conciliation Committee actually reached a common agreed position ${ }^{6}$ but the text was rejected by the European Parliament on a tied vote. At that time, the Parliament identified for specific criticism the principle that shareholder approval was required before directors could institute defensive measures in the face of a bid. The Rapporteur, Klaus-Heiner Lehne, recommended that such a requirement could only be justified if a level playing field existed for European companies facing a takeover bid and that since this was not then the case the agreement should be rejected. The Parliament also argued that the protection for employees of companies involved in the bid was insufficient and that the proposal failed to achieve a level playing field with the United States. Following this setback, the Commission established a High Level Group of Company Law Experts under the chairmanship of Jap Winter to present recommendations for resolving the matters raised by Parliament. The ensuing report ("the Winter Report" was published in early 2002." A further proposal for a Directive was introduced in 2002 taking broad account of the Winter Report's recommendations and following significant amendment, much of it last minute, a text was agreed. Directive 2004/25/EC on Takeover Bids ("the Directive") was finally adopted in April 2004 with a required implementation date of 20 May 2006.

\footnotetext{
${ }^{6}[2001]$ OJ C23/1.

7 Report of the High Level Group of Company Law Experts on Issues Related to Takeover Bids

http://europa.eu.int/comm/internal_market/company/takeoverbids/index_en.htm viewed 9 January 2007.
} 


\section{REGULATORY CHANGES}

When a directive was first considered, few European countries had detailed rules regulating takeovers. Levels of takeover activity varied dramatically from one Member State to another with the United Kingdom experiencing a substantially greater number of takeovers, particularly hostile takeovers, than other Member States. ${ }^{8}$ Consequently, the United Kingdom's City Code on Takeovers and Mergers (the City Code) was one of the first regulatory systems to be introduced in 1968. This selfregulatory code, and the London Panel on Takeovers and Mergers (the London Panel) which implements it, were created in response to public criticism of the tactics of bidders and targets in a number of prominent bid battles. $^{9}$ Since then the London Panel has supervised over 7,000 announced bids. It is clear that the London Panel's experience and expertise has been harnessed by the Commission as many of the features of the Directive such as mandatory bids, the General Principles and the prohibition on frustrating tactics are modelled on the City Code. By contrast, many EU Member States had only recently adopted regulations governing takeovers. Indeed, many of the provisions in these more recent pieces of national legislation reflect responses to issues being debated in the context of the Directive. For example, Germany's Takeover Act was introduced in 2002 and contained a mandatory bid rule. Prior to that time, Germany had been a staunch opponent of the inclusion of a mandatory bid rule in any Directive. This is consistent with the findings of Goergen et al that many countries have individually undertaken steps towards the convergence of takeover regulation. ${ }^{10}$

${ }^{8}$ McCahery J, Renneboog L, Ritter P and Haller S, "The Economics of the Proposed European Takeover Directive” in Ferrarini G, Hopt K, Winter J and Wymeersch E (eds), Reforming Company and Takeover Law in Europe (Oxford, 2004).

${ }^{9}$ Weinberg \& Blank on Takeovers and Mergers (Sweet \& Maxwell), Part III B at para.3.502.

10 Goergen, Marc, Martynova, Marina and Renneboog, Luc, "Corporate Governance Convergence: Evidence from Takeover Regulation Reforms" (April 2005). ECGI - Law Working Paper No. 33/2005 Available at SSRN: http://ssrn.com/abstract=709023 or DOI: $10.2139 /$ ssrn.709023. 
The substantial nature of the changes required to be made by Member States in order to implement the Directive varied from Member State to Member State. In Ireland, a statutory regime was already in place under the Irish Takeover Panel Act, 1997 which established the Irish Takeover Panel as the relevant supervisory authority for takeovers of Irish listed companies. (This role had been exercised until then by the London Panel. A decision was taken at the time of the split that despite the attractions of a self regulatory system, in order to ensure compliance with an Irish Panel's takeover rules and enforcement of its rulings, statutory powers were required. ${ }^{11}$ ) The Directive was implemented into Irish law by the European Communities (Takeover Bids (Directive 2004/25/EC)) Regulations 2006. ${ }^{12}$

Somewhat ironically, the UK Government found itself faced with a complicated regulatory dilemma involving the London Panel. During the earlier stages of the drafting process, it was believed that the UK would be able to retain its self-regulatory system and thus references are made in the Directive to harmonising "arrangements" as well as regulations and codes. ${ }^{13}$ Recital 7 refers to self-regulatory bodies being able to exercise supervision. Article 4.1 expressly states that the authorities appointed by Member States to supervise bids may be public authorities, associations or private bodies recognised by national law or by public authorities expressly empowered for that purpose by national law. The UK Government expressly acknowledged the considerable strengths of the system of takeover regulation overseen by the Panel, including: flexibility,

${ }^{11}$ Clarke,B "The Irish Takeover Panel Act, 1997 - A Further Cutting of the UK Regulatory Ties” (1998) 1 Palmer’s In Company 1-3.

\footnotetext{
${ }^{12}$ The Investment Funds, Companies and Miscellaneous Provisions Act 2006 subsequently introduced a number of amendments to the 1997 Act and the Regulations including a provision allowing the Irish Panel to make provision in its rules to give effect to EU law in this area. The power to make rules in the 1997 Act was not wide enough to enable the Panel to make rules directly to give effect to changes in this area arising from the Takeovers Directive and recent caselaw provides that such power must be provided in primary law.

${ }^{13}$ Article 1(1).
} 
speed and certainty in decision-making; principles-based regulation; involvement of key City and business participants in developing takeover rules and the regulatory framework; and a consensual approach to regulation amongst those involved in the markets. ${ }^{14}$ It expressed the wish to preserve these core characteristics of takeover regulation. However, under Community law, the provisions of the Directive had to be implemented by rules which have legally binding effect in some way. ${ }^{15}$ There was considerable legal uncertainty as to whether recognition of a non-statutory Code as applied by a non-statutory body even with the backup of the Listing Rules or other statutory support would constitute proper implementation of the Directive. The UK Government thus decided to provide statutory underpinning to the regulatory activities of the London Panel while seeking to give it considerable scope to decide its internal structures and operational framework. ${ }^{16}$ The City Code was given statutory effect in the Takeovers Directive (Interim Implementation) Regulations 2006 and subsequently the Companies Act 2006. The London Panel was given a number of statutory powers enabling it to make and enforce rules in relation to takeover regulation. Interestingly, the London Panel indicated that in giving its rulings, it continues to have the ability to interpret the City Code flexibly to take account of the particular circumstances of the case and that the Executive remains able to respond to such enquiries speedily. ${ }^{17}$ Indeed, it has opined that the implementation of the Directive will have little impact in practice on the Executive's dayto-day operations. ${ }^{18}$ Despite the attempts in the Directive to imbue

${ }^{14}$ DTI, Company Law Implementation of the European Directive on Takeover Bids, A Consultative Document (January 2005) para.2.11.

${ }^{15}$ DTI, Company Law Implementation of the European Directive on Takeover Bids, A Consultative Document (January 2005) para.2.12.

${ }^{16}$ DTI, Company Law Implementation of the European Directive on Takeover Bids, Government Response and Summary of Responses to the Consultative Document (November 2005) p.3.

17 The Takeover Panel, The European Directive on Takeover Bids (2005/10) (January 2005) p 2.

${ }^{18}$ Takeover Panel 2006 Annual Report. 
Member States with as much flexibility as possible by setting out merely the regulatory framework (described in the next section below), it is submitted that this may be a sanguine view. The London Panel has always had the benefit of applying the principle that the spirit as well as, or in some cases rather than, the letter of the law must be applied. Despite being subject to judicial review ${ }^{19}$ and falling within the scope of the Human Rights Act 1998, the London Panel has not yet experienced the restrictions which by definition must apply to a statutory code. It remains to be seen the extent to which this impedes its operation.

\section{FRAMEWORK DIRECTIVE}

The Directive takes the form of a framework of six general principles with which Member States must ensure compliance. The Directive then sets out a number of general requirements which Member States will have to respect through detailed implementing rules. (This is consistent with the Lamfalussey Report on the Regulation of Securities Markets. ${ }^{20}$ ) However, even these provisions of the Directive must be seen merely as minimum requirements for EU takeover regulation as Article 3(2) expressly authorises Member States to lay down additional conditions and provisions more onerous than those of the Directive for the regulation of bids.

Recital 6 expressly states that "in order to be effective, takeover regulation should be flexible and capable of dealing with new circumstances as they arise". It states that it should accordingly provide for the possibility of exceptions and derogations. Article 4(5) thus allows Member States to provide in the rules introduced pursuant to the Directive for derogations

${ }^{19} \mathrm{R}$ v Panel on Take-overs and Mergers, ex parte Datafin plc and another (Norton Opax plc and another intervening) [1987] 1 All ER 564.

${ }^{20}$ The Committee of Wise Men Report on the Regulation of European Securities Markets (2001) http://europa.eu.int/comm/internal_market/securities/lamfalussy/index_en.htm viewed 9th January 2006. The Committee was chaired by Baron Alexandre Lamfalussy. 
from the rules. This power is not however absolute. Firstly, Article 4(5) clearly states that they may only do so where the general principles are respected. Secondly, the right to derogate must be provided for in the rules Member States introduce or make $\mathrm{e}^{21}$ and not merely granted by the supervisory authorities on an ad hoc basis. What remains somewhat of a moot point is whether derogations can be granted from the general requirements which are set out in the Directive once to do so would not be contrary to the general principles.

Although the rationale for harmonising only the basic principles is obvious, one predictable and intended consequence is that that takeover regulation will be different in each Member State. Thus for example the Directive does not define "control" and it is up to each Member State to state the particular percentage figure. This takes into account differences in share ownerships structures among Member States. The optionality provisions referred to in section VI below serve to exacerbate these regulatory differences. A further and unintended contribution was made to this regulatory diversity by the drafting process itself. In many areas of the Directive, Member States are left to attempt to make sense of opaque provisions or inconsistent provisions. This means that the Directive is likely to be implemented and construed differently in each Member State, i.e. according to local legal culture and consistently with prior corporate law provisions. There are numerous examples of this. One such example is the requirement to make a mandatory bid which is triggered where a person as a result of his/her own acquisition or the acquisition of a concert party acquires control in the company. Article 5(1) requires that "such a person" must make a bid without specifying which person. In Ireland and the UK, the pre-existing mandatory bid provision allowed the Panels to determine which of the parties should make the bid and this practice has been continued. ${ }^{22}$ While this provision was maintained in Ireland and the

${ }^{21}$ Article 4(4) provides that Member States may (i) include such derogations in their national rules, in order to take account of circumstances determined at national level and/or (ii) grant their competent supervisory authorities powers to waive such national rules, to take account of the circumstances referred to in (i) or in other specific circumstances, in which case a reasoned decision must be required.

${ }^{22}$ Rule 9 of the City Code and the Irish Takeover Panel Takeover Rules 2001-2006. 
UK, different Member States may not follow suit. Furthermore, an argument could be made that this does not meet the requirements of the Directive as the obligation is not shared between the parties. Such lack of clarity can lead to litigation - often of a tactical nature.

\section{Classification}

Is the Directive a company law directive or a capital markets directive? Formally it is a directive on company law and part of the company law harmonization process. It started life as the draft $13^{\text {th }}$ Company Law Directive. It deals with company issues such as squeeze out rule and restrictions on frustrating actions. However, it also seeks to regulate the information avail to investors making the investment decision to retain their shares in the company or to sell - a capital markets issue. The Directive also deals with issues which might be said to be neither company law or capital markets law such as the provision in Article 6 of consultation rights to employees. Finally, the Directive deals with issues with both a company law and a capital markets law dimension. For example empirical studies indicate that corporate governance is becoming increasingly important to investors in making their investment decisions. ${ }^{23}$ Similarly, the SOX legislation in the US indicates that more stringent corporate governance obligations may often be the capital market regulatory response to perceived deficiencies. ${ }^{24}$ Why is this classification relevant? Although closely linked, capital markets regulation and takeover regulation serves different objectives. ${ }^{25}$ For example, disclosure regulation

${ }^{23}$ See for example McKinsey’s Global Investor Opinion Survey, 2002 or Gompers, P, Ishii J and Metrick, A. "Corporate Governance and Equity Prices.” 118 Quarterly Journal of Economics (2003) 107.

24 "EU Company Law at the Crossroads" at p.12 in Reforming Company and Takeover Law in Europe (Ferrarrini,G Hopt, K Winter J and Wymeersch E (eds) (Oxford University Press, 2004).

25 "EU Company Law at the Crossroads" at p.12 in Reforming Company and Takeover Law in Europe (Ferrarrini,G Hopt, K Winter J and Wymeersch E (eds) (Oxford University Press, 2004). 
in company law tends to be viewed as an instrument of corporate governance ensuring that the board is held accountable and allowing their performance be assessed. It also determines the extent to which a company can make distributions to shareholders under the capital maintenance rules. By contrast, disclosure regulations in capital markets law is designed to ensure the protection of investors by providing them with sufficient and timely information and the promotion of an efficient and orderly marketplace. The idea is that by placing a more liquid and efficient capital market at the service of EU, enterprise will deliver benefits in terms of competitiveness, and job creation, innovation and growth. ${ }^{26}$ From a regulatory perspective, both types of law makes different jurisdictional claims. The company law of a Member State regulates the governance of companies incorporated and with their registered offices in the State. Capital markets law of a Member State applies to companies whose securities are listed on that State's markets.

Article 4.2(a) of the Directive provides that the supervisory authority having jurisdiction to regulate a bid is that of the Member State in which the offeree company has its registered office (its "home Member State") if the securities are admitted to trading on a regulated market in that Member State. In this case, only one supervisory authority has jurisdiction and the law of that Member State clearly applies to all aspects of the bid. This provision is likely to apply to the vast majority of companies caught by the Directive as only a few companies avoid listing in their country of incorporation. However, where this situation does arise and a company's securities are not listed in its home Member State, paragraphs (b) to (e) of Article 4.2 apply and matters become a good deal more complicated. If the securities are traded on a regulated market in another Member State, the competent authority will be that of that Member State. If the securities are admitted to trading on more than one market, the competent authority will be that of the Member State on the regulated market of which the securities were first admitted to trading. If the securities were listed simultaneously, the offeree company is given the option of determining which of the Member State's supervisory authorities will have jurisdiction and of notifying the regulated market and supervisory authority on the first

${ }^{26}$ Report of Sixth meeting of the Financial Service Policy Group (11/02 2000) available at http://ec.europa.eu/internal_market/finances/actionplan/index_en.htm\#policy. 
day of trading. Where its securities are already trading prior to the implementation of the Directive, the decision is left to the supervisory authorities. However, in all these cases where the offeree's securities are not listed in its home Member State, paragraph (e) provides that jurisdiction must be divided. Procedural matters which specifically include the price, the information on the offeror's decision to make a bid, the contents of the offer document and disclosure of the bid are to be dealt with in accordance with the rules of the competent authority's Member State. By contrast, both the applicable rules and the competent authority shall be those of the home Member State for matters relating to information for employees and company law matters (specifically, the percentage of voting rights conferring control, derogations from the mandatory bid and conditions under which defensive actions may be allowed). Much discussion has revolved around the manner of implementation of paragraph (e). At one stage during the drafting process, there were demands for a definitive and exhaustive list within the Directive of issues falling within each category. Subsequently, it seemed as if this article might usefully be the subject of Level 2 implementing measures under the Lamfalussy system. It is now clear that it will be up to the supervisory authorities in each Member State to agree to a separation of responsibilities. Two problems exist with this. First, the authorities may not agree. Second, even if they do, the relevant parties may not accept what is in fact merely an interpretation of the Directive. The Directive does not provide a means for resolving such disputes. It merely requires the supervisory authorities of Member States to "cooperate”. It will thus fall to the European Court of Justice to do so. All of this will involve time and delay. This may jeopardise what has been recognised as "the special needs of the financial markets for speed on the part of decision-makers". ${ }^{27}$ It may even encourage tactical litigation. In a hostile takeover bid, one of the parties may argue that a particular issue, for example a minimum acceptance condition, has been incorrectly classified. Although as noted above, paragraph (e) will not apply to the vast majority of Directive companies at present, concerns have been raised that as European stock

${ }^{27}$ R V Panel on Takeovers and Mergers; Ex Parte Datafin plc [1987] QB 815. 
exchanges merge and new electronic markets are developed, the number of companies affected by this provision may grow. ${ }^{28}$

\section{Public Interest}

In the light of available economic evidence, the Winter Group opined that the availability of a mechanism which facilitates takeover bids is basically beneficial. $^{29}$ It cited three reasons for this: the exploitation of synergies, the opportunity to sell at a premium on market price and finally, the market for corporate control. The latter suggests that takeovers or the threat of takeovers act as a stimulant to encourage directors to adopt an optimal governance structure. ${ }^{30}$ Though beyond the scope of this paper, it is submitted that the market for corporate control as a form of external market force suffers from its reliance on a number of disputable assumptions, limited application and ambiguous empirical support. ${ }^{31}$ However, the Winter Report was emphatic in its assertion that "such discipline of management and reallocation of resources is in the long term

28 DTI, Company Law Implementation of the European Directive on Takeover Bids, Government Response and Summary of Responses to the Consultative Document (November 2005) p31.

29 Report of the High Level Group of Company Law Experts on Issues Related to Takeover Bids (2002) p.19.

30 Manne H (1965) "Mergers and the Market for Corporate Control." 73 Journal of Political Economics 110, Jensen M and Meckling W "Theory of the Firm: Managerial Behaviour, Agency Costs and Ownership Structure.” (1976) 3 Journal of Financial Economics 305 and Fama E “Agency Problems and the Theory of the Firm” (1980) 88 Journal of Political Economics 288.

${ }^{31}$ See further Clarke B “Articles 9 and 11 of the Takeover Directive (2004/25) and the Market for Corporate Control” (2006) Journal of Business Law 355-374. 
in the best interests of all stakeholders and society at large" and that these views "form the basis for the Directive". 32

Prior to the introduction of the Directive in Ireland, the evidence supported the idea that takeovers were based on the creation of synergies and that offeree shareholders received premiums but the evidence in support of the market for corporate control was weaker. A study was undertaken by the author of all 35 companies subjected to a takeover offer since the inception of the Irish Takeover Panel in $1997 .{ }^{33}$ Of the documents studied, $49 \%$ involved bids from established companies in the same industries, $36 \%$ involved bids by MBO vehicles and a further 15\% involved bids by newly established companies run by individuals often with experience in these areas. Synergistic gains were stated to be the reason behind the acquisitions from companies in the same industry. In particular, the opportunity to expand in the Irish markets was emphasised. Interestingly, all the cross-border bids in the sample (28\%) fell into this category. In terms of premiums, the average recorded for the bids was $33 \%{ }^{34}$ This is clearly attractive for the offeree's shareholders. It also explains perhaps why all but one of the companies in the sample experienced a change in control following the bid. Finally, the evidence sheds some light on the health of the market for corporate control in Ireland. On a general level, only $5 \%$ of relevant companies were subjected to a bid in any one year. ${ }^{35}$ In considering which specific bids might be the result of inefficient

32 Report of the High Level Group of Company Law Experts on Issues Related to Takeover Bids (2002) p.19.

33 The study was based on the offer documents and response circulars of the 39 takeover offers made from 1997 to 2006.

34 This does not include offers where there was no actual value for the share listing because of a lack of a market, suspension or otherwise.

35 The average number of relevant companies during the period 1997 to 2005 was 74 . The term "relevant company" is determined in accordance with section 2 of the Irish Takeover Panel Act 1997. 
management, the MBO situations would not appear relevant. ${ }^{36}$ These bids were stated to be driven overwhelmingly by perceptions of negative small cap sentiments in the Irish market. Of the acquisitions from offerors in the same industry which disclosed these details ${ }^{37}$, only one involved all the offeree's directors resigning and the remaining bids retained the CEO and/or at least half the board. Of the six bids from new offeror companies in the sample, one retained the CEO and finance director, four did not disclose whether any of the directors were resigning and only one declared that all directors were resigning. None of these companies cited poor management as the rational for the acquisition. However, before using this as evidence to question the existence of the market for corporate control, one must remember that the effect of the market for corporate control lies as much in the threat it poses to directors as the production of changes in control. It is arguable thus that where the threat operates effectively, there would not be high incidents of takeovers. All that one might conclude from the survey thus is that there does not seem to be substantial evidence of the stick being used.

While it is clearly in the public interest that the Directive operates effectively in order to achieve the positive economic effect referred to above, there is a specific group of stakeholders which is worth considering separately - employees. Traditionally in Ireland and the UK, takeover regulation has involved considering the interests of shareholders almost exclusively amongst other stakeholders. The Takeover Rules referred to employees only to the extent of requiring the offeror to include a statement in the offer document indicating: its intentions regarding the continuation of the business of the offeree and its subsidiaries; its intentions regarding any major changes to be introduced in the business, including any redeployment of the fixed assets of the target and its subsidiaries; the longterm commercial justification of the offer; and its intentions with regard to

\footnotetext{
${ }^{36}$ Even if the poor share price was caused by inept management, it would seem to pervert the market for corporate control theory, if the management themselves were able to benefit from the fruits of their ineptitude.

${ }^{37} 6$ out of the 19 bids did not disclose any details of the resignations. A further one indicated the finance director and an undisclosed number of other directors were remaining.
} 
the continued employment of the employees of the offeree and of its subsidiaries.38 In practice, this was satisfied by the inclusion of a boilerplate statement to the effect that the employees existing contractual rights would be respected. Given that this constituted an existing legal requirement, this was not particularly significant. However, the continental European idea of corporate social responsibility and the treatment of employee stakeholders embedded in many of the Member States political economies would have envisaged a greater role for employees in the takeover process. Consistent with this, the earlier drafts of General Principle 3(2)(c) in the Directive imposed a duty on the board of the offeree "to act in all the interests of the company, including employment". The wider and more inclusive form of corporate social responsibility promulgated in the US never appeared even to reach the discussion stages in respect of a European Directive.

The issue of employees constitutes a clear example of the challenges faced by the Commission attempting to find a common path in the field of takeover regulation. The UK and Ireland expressed concern at the express reference to employees in the general principles. These concerns did not stem merely from an unwillingness to compromise positions or parochial bias. In the common law jurisdictions, genuine legal uncertainty surrounded the imposition of a duty on directors to act in the interests of employees. Concern was expressed that this duty might be difficult to respect where a conflict arose between the interests of the shareholders and the interests of the employees.39 Such a conflict would arise for example where a generous offer had been made to shareholders but in circumstances where the offeror made clear its intention to dismiss a large portion of the workforce following the acquisition. At the Working Council Group examining the draft Directive, the argument was made that in Ireland and the UK, where directors were under an existing fiduciary duty to act in the interests of the company, this could cause difficulties as it might be seen as an extension of the fiduciary duties. It was argued

\footnotetext{
${ }^{38}$ Rule 24.1.
}

${ }^{39}$ The Company and Commercial Law Committee of the Law Society of Ireland made this point for example in their submission to the Commission on the draft directive. 
furthermore that the Directive is charged with protecting shareholders. This argument was accepted and the final version of the General Principle $3(2)$ (c) omitted the express reference to employees and refers merely to requiring the offeree board to act "in the interests of the company as a whole".

General Principle 3(2)(c) appears at first glance to amount to a restating of the traditional common law fiduciary duty. In itself, this would be an unusual consequence because one of the criticisms often leveled against EU corporate regulation is that it does not cover core corporate law areas such as fiduciary duties and shareholder remedies. ${ }^{40}$ However, the meaning of the term "company as a whole" remains somewhat ambiguous. In the common law jurisdictions the term "acting in the interests of the company" in the context of fiduciary duties has typically been viewed as acting in the interests of shareholders. ${ }^{41}$ The term in the Directive is clearly open to different interpretations and yet none is provided. The recitals are not helpful in this regard. While the first recital refers to the necessity to coordinate safeguards required by Member States "for the protection of the interests of members and others", the other recitals refer only to shareholders. Rather than defining the term, Ireland and the UK have imported the provision directly into the implementing rules. (While, the London Panel's Code Committee considers that the Panel's primary focus in considering breaches of the Code is and will continue to be the consequences for shareholders, "on reflection" it noted that breaches of the Code may also have consequences for other people. ${ }^{42}$ ) The lack of a clear meaning for this term may give rise to difficulties for companies seeking to comply with this general principle and for Member States eager to ensure compliance.

\footnotetext{
${ }^{40}$ Enriques L."EC Company Law Directives and Regulations: How Trivial Are They?” Law Working Paper No 39/2005 (May 2005).

${ }^{41}$ Clarke B, "Regulating Poison Pill Devices” (2004) 4 Journal of Corporate Law Studies 51-75.

42 RS2005/5, Panel Response Statement, 21/04/2006, The implementation of the Takeovers Directive, p.15.
} 
A further potential difficulty with the inclusion of this term in the general principles is that it is not clear whether it gives rise to directly enforceable rights. While pre-existing companies legislation in the UK and Ireland acknowledges the duty of directors to act in the interests of employees, the duty is expressly stated to be owed to the company and enforceable only by the company. ${ }^{43}$ However, the Directive imposes an obligation on Member States to ensure compliance with this general principle without such a limitation. One might question thus whether the existence of a general principle in the takeover rules, a narrow statutory duty and a restrictively interpreted common law duty in Ireland and the UK is sufficient to ensure compliance with the Directive. From an academic perspective, one might also consider the effect of such a broad and unrestricted duty as that included in the Directive on the existing common law position. Could this perhaps give rise to one of the "collisions" 44 Black describes where the regulatory provisions have direct and unsettling effect on common law calling into question traditional common law conceptualisations.

In addition to the General Principle, certain other provisions in the Directive provides rights to employees. However, these rights constitute rights to information and to consultation only. So for example, Article 6(3)(i) provides that the offeror must include in the offer document "the offeror's intentions with regard to the future business of the offeree company and, in so far as it is affected by the bid, the offeror company and with regard to the safeguarding of the jobs of their employees and management, including any material change in the conditions of employment, and in particular the offeror's strategic plans for the two companies and the likely repercussions on employment and the locations of the companies' place of business”. Article 9(5) requires the board of the

${ }^{43}$ In some cases such as Greenhalgh v Arderne Cinemas Ltd [1951] Ch. 286, Evershed MR suggested that the interests of the present shareholders should be considered. In Gaiman v National Association for Mental Health [1972] Ch. 317 and Dawson International plc v Coats Paton plc (1988) 4 B.C.C. 305 the interests of the company were equated with the interests of present and future shareholders.

${ }^{44}$ Black J. "The Case of Finance” at p.41 in Regulating Law, Parker C, Scott C, Lacey N, Braithwaite J (eds, Oxford, 2004). 
offeree company to set out its views on the effects of the implementation of the bid on all the company's interests and specifically employment, and on the offeror's strategic plans for the offeree and the likely repercussions on employment and the locations of the companies' place of business as set out in the offer document”. The Winter Report noted that such provisions were adequate and that any further concerns for the interests of employees should be addressed by specific legislation providing for information and consultation of employees and for their protection in the event of a bid leading to restructuring. ${ }^{45}$ Limited though that are, even these disclosure requirements might be difficult to comply with in all cases. For example in a hostile bid, the offeror may not have access to sufficient information to allow it make any meaningful proposals. Similarly, the offeree board are unlikely to be aware of any substantive plans. Such difficulties arose in the hostile bid by Ryanair for Aer Lingus in 2006.

\section{HARMONISATION AND THE CREATION OF A LEVEL PLAYING FieLd}

One of the most controversial aspects of the harmonization process in the takeover market in the EU has been the creation of a level playing field. Because of the aforementioned structural and regulatory differences between the various Member States, it was acknowledged that takeover bids could not be undertaken with the same expectation of success in different Member States. ${ }^{46}$ Thus shareholders in Member Sates did not have equivalent opportunities to tender their shares. This is referred to as the 'lack of a level playing field'. The Winter Committee was set the task of reviewing whether and to what extent a level playing field for takeover bids could and should be created with respect to the mechanisms and

45 Report of the High Level Group of Company Law Experts on Issues Related to Takeover Bids (2002) p.16.

${ }^{46}$ Report of the High Level Group of Company Law Experts on Issues Related to Takeover Bids (2002) p.19. 
structures, allowed and created under company law in Member States, which may frustrate or inhibit takeover bids. The Committee acknowledged at the outset that any approach on this basis would leave the various general and structural differences existing in Member States untouched. However it expressed the opinion that its recommendations with respect to company law mechanisms and structures would, in addition to market driven changes, mark an important step forward in developing a general level playing field for takeover bids in the EU. ${ }^{47}$ The Report firmly acknowledged that there was a need for a level playing field for shareholders in the EU and that a directive on takeover bids was an important part of it.

As a consequence of its deliberations, the Winter Report suggested that a guiding principle of any European company law regulation aimed at creating a level playing field should be the right of shareholders to make the ultimate decision in respect of whether to tender their shares and at what price. It concluded that the risk was too great that their own selfinterests would lead directors would engage in actions which would frustrate hostile takeovers. ${ }^{48}$ This view was accepted by the EU legislature and Article 3(1)(c) provides inter alia that "the board of an offeree company ... must not deny the holders of securities the opportunity to decide on the merits of the bid". Article 9(2), giving effect to this principle, requires the specific prior authorisation of shareholders for "any action ...which may result in the frustration of the bid other than seeking alternative bids" 49 and specifically "before issuing any shares" at least from the time the offeree is approached. Article 9(3) introduces a requirement for shareholder approval of "decisions taken ... and not yet partly or fully implemented” before the beginning of the period during

47 Report of the High Level Group of Company Law Experts on Issues Related to Takeover Bids (2002) p.20.

48 Report of the High Level Group of Company Law Experts on Issues Related to Takeover Bids (2002) p 21.

${ }^{49}$ Such an exemption is also consistent with practice in Ireland and the UK. Indeed in two of the three hostile bids made to Irish companies during the period of study, this was the successful form of defence utilised by management. 
which Rule 9(2) applies where the decisions do not form part of the normal course of the company's business and where their implementation "may result in the frustration of the bid". The prohibition applies to all decisions which have a chance of frustrating the bid. This appears extremely far reaching until one considers that Art 9(3) expressly excludes "decisions" which have been "partly or fully implemented". Transposing this particular provision was challenging as no guidance was given as to what constitutes a "decision" or how one might be partly implemented. ${ }^{50}$ The difficulty was avoided in the UK and Ireland by the repetition of the same wording in the Takeover Rules without the benefit of explanatory notes. This may give rise problems at a later stage when the provision is tested.

The Winter Report also stated that European company law regulation aimed at creating a level playing field should be guided by a second principle - proportionality between risk-bearing and control. ${ }^{51}$ Article 11 introduces the break-through rule which was designed to increase the number of takeovers in the EU by eliminating these corporate governance arrangements which might otherwise impede takeovers. ${ }^{52}$ The Winter Report argued that the presence of differentiated voting rights, voting caps, pyramid structures and other such structures in Member States' company law was generally inconsistent with the principles of shareholder decision making and proportionality between risk-bearing capital and control. The rule's desired effect thus was to transform a bid on a company where there is one dominant blockholder into a bid for a company with dispersed ownership. It allows the bidder thus to acquire control without necessarily persuading the dominant blockholder to sell. Article 11(2) and (3) dis-apply certain restrictions when a bid has been

${ }^{50}$ Clarke B, "Articles 9 and 11 of the Takeover Directive (2004/25) and the Market for Corporate Control” (2006) Journal of Business Law 355-374.

${ }^{51}$ Report of the High Level Group of Company Law Experts on Issues Related to Takeover Bids, p.20.

${ }^{52}$ Report of the High Level Group of Company Law Experts on Issues Related to Takeover Bids, p 29. 
made public. During the acceptance period, Art 11(2) dis-applies vis a vis the offeror restrictions on the transfer of securities provided for in the articles of association of the offeree and restrictions on the transfer of securities in contracts between the offeree and its shareholders or between shareholders entered after the adoption of the Directive. Article 11(3) provides that restrictions on voting rights provided for in the articles of association of the offeree and restrictions on voting rights in contracts between the offeree and its shareholders or between shareholders who entered after the adoption of the Directive shall not have effect at the general meeting of shareholders "deciding on any defensive measures" in accordance with Art 9. In addition, Art 11(3) provides that multiple-vote securities will carry one vote each at the general meeting of shareholders which "decides on any defensive measures" in accordance with Art 9. Article 11(4) provides that where following a bid, the offeror holds $75 \%$ or more of the capital carrying voting rights, none of the above restrictions and none of the "extraordinary rights" of shareholders in the articles of association concerning the appointment/removal of board members shall apply. Furthermore, multiple-vote securities will carry one vote each at the first general meeting of shareholders following closure of the bid, called by the offeror to amend the articles or appoint/remove directors. The offeror is entitled to call such a meeting on short notice once at least two weeks notice is given. Article 11(6) and (7) provides an exception to the application of Art 11(3) and (4) if the restriction on voting rights is compensated for by specific pecuniary advantages" or if the rights are held by Member States. The Winter Report noted that the application of such a rule after a successful bid was designed to:

strike a balance between, on the one hand, the need, at least for the time being, to allow differences in the capital and control structures of companies in view of the current differences between Member States, and on the other hand, the need to allow and stimulate successful takeover bids to take place in order to create an integrated securities market in Europe. ${ }^{53}$

${ }^{53}$ Report of the High Level Group of Company Law Experts on Issues Related to Takeover Bids, p 30. 
As a consequence of the rule, a blockholder who wishes to retain control must thus compete for the company. In the event that financing is available thus, the party with the higher valuation will prevail. While Berglöf and Burkart thus argued that, in the absence of wealth constrains, the breakthrough rule ensures an efficient allocation of corporate control, ${ }^{54}$ this view is not without its critics. ${ }^{55}$ It should be noted that it is possible that companies could avoid the rule by increasing ownership to more than $25 \%$ or reincorporating outside the EU. Alternatively they could introduce structures outside the scope of the rule such as cross-holdings or pyramids. Finally, implementing the rule may cause difficulties as a result of the requirement in the Directive to provide compensation in certain cases.56 This may even allow the rule to be used in order to render takeovers more unattractive.

In the debates on the Directive in the European Parliament in 2001, the argument was made that the introduction of a prohibition on frustrating action would create an unlevel playing field between the EU and the United States. The Winter Report acknowledged that boards of American companies generally have a broad discretion to put up defensive devices under the business judgement rule and that many individual states have

${ }^{54}$ Berglöf E and Burkart M, “European Takeover Regulation” (2003) 18 Economic Policy 171.

55 Gugler K, Corporate Governance and Economic Performance (Oxford University Press, 2001), Bennesden M and Nielsen K, “The Impact of a Break-Through Rule on European Firms” (Working Paper, Copenhagen Business School, 2002, Khachaturyan A, “Can Bolkestein Finally Break the Takeover Directive Deadlock?” (Commentary, Centre for European Policy Studies, 12 January 2005), http://www.ceps.be/Article.php?article_id=68 viewed 9 January 2006, DTI, Company Law Implementation of the European Directive on Takeover Bids, Government Response and Summary of Responses to the Consultative Document (November 2005) n 19, p 25, Hertig G and McCahery J "Company and Takeover Law Reforms in Europe: Misguided Harmonization Efforts or Regulatory Competition” (2003) 4 European Business Organization Law Review 179 and Bebchuk L and Hart O, "A threat to Dual-class Shares”, Financial Times (31 May 2002).

${ }^{56}$ B. Clarke, “Articles 9 and 11 of the Takeover Directive (2004/25) and the Market for Corporate Control” (2006) Journal of Business Law 355-374. 
enacted laws specifically permitting the board to consider other interests than shareholders' interests. However, it strongly argued that the American approach was likely to be less beneficial to the development of efficient integrated capital markets in Europe. It cited three arguments to support this view. Firstly, while American companies generally have a broad discretion to defend themselves under the business judgment rule, it argued that this discretion operates in a widely differing legal and capital market environment. It suggested that American boards are subject to greater pressure than their European counterparts to enhance shareholder value. This pressure comes from non-executive directors on the board, investment banks and advisors and in particular from institutional investors. Board behaviour is widely transparent under the legal transparency rules and the intense scrutiny of the media. In addition, proxy contests are more likely to ensue and liability suits against directors are more common as derivative actions are easier and the judicial system is better equipped. Secondly, the Winter Report noted while the relatively broad discretion of the board to defend against takeover bids has certainly led to a number of takeover bids not being successful or not being made at all, takeover activity in the American capital markets is intensive and forms an essential part of its financial and economical structure. It noted that European companies have benefited from this and evidence gathered on mergers and acquisitions activity between 1990 and 2000 indicates that the existence of defensive mechanisms have not deterred European companies. By contrast, the existence of barriers in some Member States has resulted in control over listed companies being incontestable. The Winter Report concluded that this is undesirable in the European context, as an integrated capital market has to be build up in order for business to fully benefit from and make effective use of the integrating internal market in Europe. Thirdly, the Winter Report noted that certain defensive measures in the US are prompted by the ability of bidders to obtain control through the making of a partial bid. Such bids are not possible under the mandatory bid provision in the Directive. Finally, it noted that antitakeover rules are controversial even within the United States and that while some accept them as the outcome of regulatory competition among the states and effective lobbying by the business community, there is a large body of both economic and legal literature arguing that they should be prohibited. The Winter Report argued that it was not desirable that the American approach to defensive actions be followed in Europe but rather 
a system of regulation which is the best suited to its environment and objectives. $^{57}$

Article 12(1) provides that Member States may decide not to require companies registered in their jurisdiction to apply the prohibition on frustrating action in Article 9 and the break-through rule in Article 11. Article 12(2) provides that if Member States "make use of this option" they must still grant companies the reversible option of applying the Articles.58 One view is that as a consequence of Article 12(1), the harmonisation process has been damaged and the goals of the Directive undermined. An alternative view set out below is that competition is preferable to harmonisation in this regard. Before dealing with this issue however, one must consider a more straightforward threat to the creation of a level playing field and one which is not dealt with by the Directive as a result of regulatory gaps in this area - the frustration of bids through persuasion by potentially conflicted offeree directors.

\section{REGULATORY GAPS}

A further defence available to the offeree board is that of dissuading the offeree's shareholders from accepting the offer. In the Irish survey, this was the successful form of defence utilised by management in the third hostile bid. Indeed, it is very telling to note that in all cases in the Irish study, shareholders followed the advice of their directors. This is consistent with international empirical studies which have consistently found that the recommendations of target company directors in takeovers is the most important variable in determining takeover outcome. ${ }^{59}$ This

${ }^{57}$ Report of the High Level Group of Company Law Experts on Issues Related to Takeover Bids, p.39-42

58 This decision must be taken by the shareholders in a general meeting in accordance with the rules applicable to the amendment of their articles of association.

59 O’Sullivan, N and Wong, P. "Board Composition, Ownership Structure and Hostile Takeovers: Some UK Evidence” (1999) 29 Accounting and Business Research 139-155, Cotter, J.S., Shivdasani, A. and Zenner, M. "Do Independent Directors Enhance Target 
increases the urgency of ensuring that effective corporate governance mechanisms exist to regulate the process of making these recommendations in order to ensure that directors are acting in the best interests of the company and its shareholders. However a mixture of binding "hard law" and non-binding "soft law" regulates the process of making these recommendations.

The Winter Report advised that the offeree board's insight into, and responsibility for, the strategy and day-to-day affairs of the company enable and require it to advise the shareholders on the takeover bid. It thus opined that the board is best placed "to express its views on the consequences of the bid for the company and its business and on the attractiveness of the terms of the bid for the shareholders". ${ }^{60}$ Consistent with this view, Article 9(5) of the Directive obliges the offeree board to draw up and make public a document setting out its opinion of the bid and the reasons on which it is based. However, absolutely no reference is made to the composition of the board giving such advice. There is no requirement, for example for directors with a particular conflict of interest to stand down. The General Principles merely require that the board of the offeree "act in the interest of the company as a whole". ${ }^{61}$ While this duty clearly applies to the giving of advice to shareholders, as noted above in section V, its implementation casts serious doubts on its usefulness in this regard. The Higgs Report acknowledged the "natural potential for conflict

Shareholder Wealth During Tender Offers?”(1997) 39 Journal of Financial Economics 343, Holl, P. and Kyriazis, D. "The Determinants of Outcome in UK Takeover Bids" (1996) 3 International Journal of Economics and Business 165-184, Cotter, JS. And Zenner, M. "How Managerial Wealth Affects the Tender Offer Process" (1994) 35 Journal of Financial Economics 63-97, Eddey, PH. And Casey, RS. "Directors Recommendations in Response to Takeover Bids: Do They Act in their Own Interests" (1989) 14 Australian Journal of Management 1-28 and Walking, R. "Predicting Tender Offer Success: A Logistic Analysis” (1985) 20 Journal of Financial and Quantitative Analysis 461-478.

60 Report of the High Level Group of Company Law Experts on Issues Related to Takeover Bids, p 20.

${ }^{61}$ Article 3(2)(c). 
between the interests of executive management and shareholders" in the making of a range of routine decisions such as remuneration or audit. ${ }^{62}$ In such circumstances, the Report noted that the legal duty on directors to act in the best interests of the company in itself is "insufficient to give full assurance that these potential conflicts will not impair objective board decision-making". ${ }^{63}$ Yet, in the more extreme circumstance of a takeover bid, only this duty is prescribed by the Directive. It is submitted thus that by failing to regulate this crucial area of corporate governance, the Directive is failing in its objective to protect fully the interests of shareholder and to create a level playing field.

This area is not regulated by existing corporate governance rules. At the European level, both a Commission sponsored review of the main corporate governance codes relevant to the $\mathrm{EU}^{64}$ and the High Level Group of Company Law Experts in its final report ${ }^{65}$ advised against establishing an EU corporate governance code. The latter report noted that while fixed rules in primary legislation may offer "the benefits of certainty, democratic legitimacy and strong possibilities of enforcement" this comes at "the cost of little or no flexibility, and disability to keep pace with changing circumstances.” It specifically recommended making use of alternative forms of regulation including "soft law" in the corporate governance area. In the 2003 Action Plan, the Commission agreed that there was no need for an EU corporate governance code. It did however emphasise the need for any regulatory response at European Union level to be firm in the principles as well as flexible in application. As part of this

${ }^{62}$ Higgs, D. Review of the Role and Effectiviness of Non-Executive Directors (January 2003), para.9.2.

63 Higgs, D Review of the Role and Effectiviness of Non-Executive Directors (January 2003), para.9.3.

64 Comparative Study of the Corporate Governance Codes relevant to the European Union and its Member States : http://europa.eu.int/comm/internal_market/ en/company/company/news/corp-gov-codes-rpt_en.htm

${ }^{65}$ Final Report of the High Level Group of Company Law Experts on a Modern Regulatory Framework for Company Law in Europe (4/11/2002). 
process, a recommendation on non-executive directors was planned which considered the nature of board independence. By using a non-binding instrument, it was intended that Member States would develop their regulatory environment along similar lines rather than agreeing a single detailed solution - the process of convergence would thus be flexible. ${ }^{66}$ The EU Consultation Paper on the Role of Non-Executive or Supervisory Directors of Listed Companies and on the Committees of the (Supervisory) Board in 2004 explained that precise definitions of "independence" vary in different codes and there is an absence of "a universal understanding of what independence precisely entails". ${ }^{67}$ Similarly, the Recitals to the Recommendation on the Role of NonExecutive or Supervisory Directors of Listed Companies and on the Committees of the (Supervisory) Board in 2005 note that "in view of the complexity of many of the issues at stake, the adoption of detailed binding rules is not necessarily the most desirable and efficient way of achieving the objectives pursued."68 Like other forms of soft law, this leads to criticism that it lacks the clarity and precision needed to provide predictability and a reliable framework for action. ${ }^{69}$

In the absence of an EU corporate governance code, each Member State deals with this unilaterally. The Combined Code (2006) applies in Ireland, as in the UK, on a "comply or explain basis" for listed companies. It provides that the decision as to whether a director is independent "in character and judgment" rests with the board which must decide whether there are "relationships or circumstances which are likely to affect, or

${ }^{66}$ Rickford J "Corporate Governance in the UK, Company Law and Corporate Governance Code” in European Corporate Governance in Company Law and Codes, a Report prepared for the European Corporate Governance Conference of October 18, The Hague, The Netherlands.

${ }^{67}$ para.2.2.3

68 2005/162/EC, Recital 4.

69 Trubek, D., Cottrell, P. and Nance, M “ “Soft Law” "Hard Law” and European Integration: Toward a Theory of Hybridity” (2005) Legal Studies Research Papers Series Paper No.1002. 
could appear to affect, the director's judgment”. The Code is not sufficient to ensure a level playing field. Firstly, the Code may be avoided by a company merely explaining non-compliance or by adopting its own definition of the term "independent" or "conflict of interest." Secondly, the Code is further weakened by the statement that it is up to the Board itself to determine what constitutes “independence.” Finally, the provision in the Code does not apply to specific decision making scenarios. It only applies to the general board position. What it refers to is independence from the company, not, for example, independence from a bidder. Although the EU Recommendation provides for periodic reconfirmation of independence, ${ }^{70}$ it does not provide for reconfirmation on an issue by issue basis. For this reason, the guidelines pertaining to independence in the Code and Recommendation might be said to be merely illustrative.

The Irish Takeover Rules states clearly that any director with a conflict of interest should be excluded from the formulation and communication of advice to shareholders. ${ }^{71}$ They provide furthermore that the nature of the conflict should be explained clearly to the shareholders in any document issued by the offeree. ${ }^{72}$ The City Code is less prescriptive merely stating in that directors with a conflict "should not normally be joined". ${ }^{73}$ Even in such closely aligned Rules as those of the UK and Ireland and in countries with similar corporate cultures, it is clear thus that a disparity of treatment of directors is possible. The non-statutory Notes to the Irish Rules give three examples of circumstances in which a conflict will exit. Unfortunately, these are not necessarily consistent with the definitions in the Code. ${ }^{74}$ For example, where the director will have an ongoing role in

\footnotetext{
${ }^{70}$ Article 13.3.2.

${ }^{71}$ Rule 3.1.

${ }^{72}$ Rule 25.1(d).

${ }^{73}$ Note to Rule 25.1 .

74 "Board Advice During Takeovers" Conference "Soft Law, Soft Regulation? The Implications for Regulatory Practice”, Anglia Ruskin University, Cambridge (13th September 2006).
} 
the new company the takeover rules are more likely to allow the director advise whereas under the Combined Code a material business relationship signifies a conflict. The existence of these differences may be positively unhelpful in the determination of independence in the context of a takeover Yet this is one of the consequences of operating within a hybrid system where hard and soft law operate in the same policy domain. The facets of soft law which appear to make it the appropriate form of regulation can also lead to significant difficulties in terms of application and enforcement. A study of the 39 offer documents reveals that while $31 \%$ of directors declined to participate in the advisory team, $69 \%$ felt able to give advice to shareholders. In $29 \%$ of the bids made, it was declared that at least some of the advisers would become part of the new board or become consultants to the newly acquired company. ${ }^{75}$ In a further $29 \%$ of the bids, all advisers were expressly stated to have no further role. However, in the remaining $48 \%$ of cases, there was no disclosure at all as to the future role, if any of the directors. In these cases, the shareholders did not have the benefit of this information in evaluating the advice. Clearly, hard rules would be difficult to formulate in relation to independent directors as in practice "one size does not fit all” and there are a myriad of different definitions of independence all with different criteria. ${ }^{76}$ It is submitted that a description of the nature of independence could have been set out clearly in the Directive and the relevant supervisory authorities rather than the board made the final arbiter of independence. (A somewhat similar treatment is given in the Directive to the definition of "concert party”.) As things stand, it appears that this aspect of corporate governance has fallen between two regulatory stools. This might be said to support a criticism which is often made of soft law

\footnotetext{
${ }^{75}$ In four of these cases, the majority of the advisers remained, in one an equal number remained, in five a minority remained (although often in an important role like CEO or financial director) and in one an unidentified minority remained.

${ }^{76}$ Higgs D Review of the Role and Effectiviness of Non-Executive Directors (January 2003), para.9.8.
} 
that it undermines EU legitimacy because it creates expectations but does not or cannot bring about change. ${ }^{77}$

\section{REGULATORY COMPETITION}

Viewing takeover regulation through a regulatory lens leads to the question of whether the effectiveness of the mechanisms could be improved. As noted above, the Directive is a minimum standards directive which contains a number of substantive provisions which have been rendered optional as a result of the inclusion of Article 12(1). The European Council viewed Article 12(1) as necessary in order to take into account the existing differences in Member States' company law mechanisms and structures. Yet its introduction has led to much controversy. Commissioner Bolkestein maintained that it would send the wrong message to the markets. The fact that it was officially reported that most Member States accepted the final text of the Directive on the basis of the Rapporteur's view that "half a loaf is better than none" and the need to terminate "this never ending story" "78 would not have allayed fears that this was merely an exercise in expediency. A more benign view was taken by Nilsen who welcomed the compromise as "a good solution which enables Member States with different types of market economies to preserve their unique comparative advantages, promoting a more competitive Europe as a whole". ${ }^{79}$ The latter view forms part of a wider debate in the regulation of European company law concerning the merits of introducing

77 Trubek D, Cottrell P and Nance M “ "Soft Law" "Hard Law" and European Integration: Toward a Theory of Hybridity” (2005) Legal Studies Research Papers Series Paper No.1002.

${ }^{78}$ Lehne, K COD/2002/0240, EP: legislative opinion, 1st reading or single reading (16/12/2003),

http://www.europarl.eu.int/oeil/FindByProcnum.do?lang=2\&procnum=COD/2002/0240 viewed 9 January 2006.

${ }^{79}$ Nilsen A, "The EU Takeover Directive and the Competitiveness of European Industry”, The Oxford Council on Good Governance Economy Analysis, No 1, p 3. 
competition between national corporate law regimes. ${ }^{80}$ Regulatory competition implies that national legislatures compete to attract firms to operate subject to their laws. ${ }^{81}$ As Collins noted, "in the context of globalisation and regulatory competition between nation states, national governments need to be concerned that their laws governing commercial transactions do not put their economies at a competitive disadvantage, with the potential deleterious consequence of driving capital investment and business towards other jurisdictions." ${ }^{82}$ However, the process of legislative competition is often criticized as leading to "a race to the bottom". In the US, the debate concerning the dynamics of regulatory competition is most often associated with the case of Delaware. The argument is often made that because shareholders have insufficient control over the decision to reincorporate, directors choose a jurisdiction such as Delaware which facilitates management entrenchment. ${ }^{83}$ However, the contrary argument is also made that directors would not engage in action perceived as detrimental to investors because of fears of a consequential negative reaction by the capital markets leading to an increase in the

${ }^{80}$ McCahery J and Hertig G “An Agenda for Reform at p. 26 in Reforming Company and Takeover Law in Europe Ferrarini G, Hopt K, Winter J and Wymeersch E (eds). For an excellent description of the theories and varieties of regulatory competition see Deakin $S$ “Legal Diversity and Regulatory Competition: Which Model for Europe?” (2006) Centre for Business Research, University of Cambridge, Working Paper No.323.

${ }^{81}$ Indeed Zumbansen argues that not only do governments compete but whole legal, social, political and economic cultures, their current states and their historical narratives compete. (Zumbansen, P, "Spaces and Places: A Systems Theory Approach to Regulatory Competition in European Company Law" (May 16, 2006). CLPE Research Paper No. 9/2006 p.37.)

${ }^{82}$ Collins, H at p.13 in Regulating Law, Parker C, Scott C, Lacey N, Braithwaite J (eds, Oxford, 2004)

83 Bebchuk L "Federalism and the Corporation: The Desirable Limits on State Competition in Corporate Law” (1992) 105 Harvard Law Review 1435, Bebchuk, L and Hamdani, A "Vigorous Race or Leisurely Walk: Reconsidering the Competition over Corporate Charters" (2002) 112 Yale Law Journal 553, available at SSRN: http://ssrn.com/abstract=325520 and Carey W "Federalism and Corporate Law: Reflections upon Delaware” (1974) 83 Yale Law Journal 663. 
company's cost of capital. ${ }^{84}$ It is said thus that market forces require directors to choose a beneficial regime and a "race to the top" ensues. ${ }^{85}$ This brings benefits such as reduced costs, greater expertise and legal certainty. ${ }^{86}$ While lessons may be learned from the US, as Deakin pointed out the Delaware experience is unlikely to be repeated in the EU as the EU is on a different trajectory reflecting the particular conditions under which the national systems evolved and under which the harmonization programme developed. ${ }^{87}$ Although it was argued that there were substantive legal and procedural barriers to the establishment of regulatory competition between EU jurisdictions, ${ }^{88}$ as a consequence of a number of European Court of Justice decisions, ${ }^{89}$ regulatory competition now appears

${ }^{84}$ See for example Winter R " State Law, Shareholder Protection, and the Theory of the Corporation" (1977) 6 J. Legal Studies 251 and Easterbrook F and Fischel D "Voting in Corporate Law" (1983) 26 Journal of Law and Economics 395.

85 Romano R "Is Regulatory Competition a Problem or Irrelevant for Corporate Governance?” ECGI Law Working Paper Series, Working Paper No.26/2005. See also Heine K and Kerber W "European Corporate Laws, Regulatory Competition and Path Dependence” (2002) 13 European Journal of Law and Economics 47.

${ }^{86}$ Romano R "Law as Product: Some Pieces of the Incorporation Puzzle" (1985) 1 JL Econ \& Org 225. See also Carney WJ “The Political Economy of Competition for Corporate Charters “ (1997) 26 Journal of Legal Studies 303.

${ }^{87}$ A detailed evolution of the EU company law harmonization programme is set out in McCahery, J and Vermeulen, E "The Changing Landscape of EU Company Law" (September 2004) TILEC Discussion Paper No. DP2004-023, available at SSRN: http://ssrn.com/abstract=871075.

${ }^{88}$ Scharpf F, Governing in Europe, Effective and Democratic? (Oxford University Press, 1999) p.101.

89 These include Case C-212/97, Centros Ltd v Erhvervs-og Selskabssyrelsen [1999] ECR I-1459, Case C-208/00 Uberseering BV v Nordic Construction Company Baumanagement GmbH (NCC) [2002] ECR I-9919, Case C-167/01 Kamel van Koophandel en Fabrieken voor Amsterdam v Inspire Art Ltd [2003] ECR I-10155. See Deakin S "Legal Diversity and Regulatory Competition: Which Model for Europe?" (2006) 12 European Law Journal 440 for a discussion of the impact of the Centros case on regulatory competition in the EU. 
more likely. A recent survey of international companies incorporating in the U.K. between 1997 and 2005 indicated a large increase in new incorporations of limited liability firms from EU Member States following these decisions. ${ }^{90}$ The study found that incorporation costs, in particular minimum capital requirements and delays in incorporation, are significant influences on location decisions. While many argue that effective competition takes place on the basis of differences in taxation, labour law and environmental law rather than company law, ${ }^{91}$ major jurisdictions such as France and Germany have already instituted reforms to their corporate law regimes to stem the flow of firm migration particularly to the UK. ${ }^{92}$

Will competition lead to a race to the bottom or to the top? Deakin identified "a reflexive approach" to EU corporate regulation which reflects the differences among Member States' systems of corporate law in order to allow for mutual learning processes in the context of European lawmaking. ${ }^{93}$ In such a continuing process, the law is thus designed to underpin and encourage an autonomous processes of adjustment. Deakin explained that by placing limits on competition "harmonization may aim to preserve the autonomy and diversity of national legal systems, while at

${ }^{90}$ Becht, Marco, Mayer, Colin and Wagner, Hannes F., "Where Do Firms Incorporate?" (October 2006). CEPR Discussion Paper No. 5875 available at SSRN: http://ssrn.com/abstract=953820. The study found that that incorporation costs, in particular minimum capital requirements, and delays in incorporation are significant influences on firms' location decisions.

91 Wymeersch, Eddy, "Centros: A Landmark Decision in European Company Law" (October 1999). Financial Law Institute Working Paper 99-15. Available at SSRN: http://ssrn.com/abstract=190431 and Ferran E, Company Law Reform in the UK, Working Paper (2001) available at SSRN: http://ssrn.com/abstract=294508.

92 Baums, Theodor, "Company Law Reform in Germany"3 J Corp Law Studies 181 (2003) Available at SSRN: http://ssrn.com/abstract=329962 This reform involved the issuance of a Corporate Governance Code, the introduction of a "law on transparency and disclosure" (Transparenz- und Publizitatsgesetz) and the reform of the German Stock Corporation Act (Aktiengesetz).

93 Deakin S "Regulatory Competition versus Harmonisation in European Company Law” ESRC Centre for Business Research, Working Paper 163/2000. 
the same time seeking to steer or channel the process of evolutionary adaptation of rules at state level". ${ }^{94}$ Harmonisation may thus be seen as "a guarantor of diversity in the laws and practices of different Member States" and an encouragement of "innovation in forms of self regulation in the corporate sphere". 95 Forstinger described the process as one under which "[m]inimum standards are seeking to promote diverse, local-level approaches to regulatory problems by creating a space for autonomous solutions to emerge". ${ }^{96}$ Allowing more choice may thus encourage both EU and national lawmakers to design value-maximising provisions and, where there is adequate competition, to engage in innovative lawmaking. ${ }^{97}$ This may result in specialisation rather than convergence. ${ }^{98}$

In the takeover context, Winter noted that the Directive clearly sets the benchmark of Articles 9 and 11 being applied by Member States and that hopefully market pressure would provide incentives to adopt this benchmark. ${ }^{99}$ However, Vermeulen questioned the likelihood of market-

94 Deakin S "Regulatory Competition versus Harmonisation in European Company Law” ESRC Centre for Business Research, Working Paper 163/2000 at p.31.

95 Deakin S "Regulatory Competition versus Harmonisation in European Company Law" ESRC Centre for Business Research, Working Paper 163/2000 at p.41.

${ }^{96}$ Forstinger C, Takeover Law in the EU and USA: A Comparative Analysis (Kluwer Law International, 2002) at 159

${ }^{97}$ An Agenda for Reform at P.38 in Reforming Company and Takeover Law in Europe,

G Ferrarrini, K Hopt, J Winter and E Wymeersch (eds) and Hertig G and McCahery J "Company and Takeover Law Reforms in Europe: Misguided Harmonization Efforts or Regulatory Competition?” ECGI Law Working Paper 12/2003 at p.4.

${ }^{98}$ Armour, John, "Who Should Make Corporate Law? EC Legislation versus Regulatory Competition" Current Legal Problems, Vol. 48, 2005 Available at SSRN: http://ssrn.com/abstract=757205.

99 Winter J, "EU Company Law at the Cross-Roads" in Reforming Company and Takeover Law in Europe, Ferrarini G, Hopt K, Winter J and Wymeersch E (eds), p 18. 
induced reform as a result of the strong coalition of interest groups and other path-dependent forces. ${ }^{100}$ When the Winter Committee originally considered whether enforcement of the shareholder decision-making principle and the proportionality principle might be left to market forces, it agreed that this might be possible in a fully integrated and well developed securities market. Such a market would be able to judge correctly the cost of capital of companies with capital and control structures which deviate from these principles and alternative investments would be available to investors. However, the Winter Committee acknowledged that the conflict of interest of the board might lead to market failure in the principle of shareholder decision-making. Secondly, it acknowledged that efficient markets do not exist across Europe. It opined that the securities markets in Member States differ widely in levels of development and in most Member States, they would not be able efficiently to judge companies which do and do not adhere to these two principles. The Winter Report stated that the more and less developed markets must be integrated on a European level to enable the restructuring of European industry and the integration of European securities markets to proceed with reasonable efficiency and speed. It also noted that investor protection tends to be weaker in markets where the two principles are not generally followed. Consequently, in order to establish securities markets in the European Union which are both efficient and provide an adequate level of investor protection, the Winter Committee advised that the two principles must be specified in more detailed rules which are binding in the Member States. ${ }^{101}$ Whether the European Parliament's failure to do so impedes the ultimate attainment of the Directive's objectives as the Winter Committee predicted or whether the balance struck in the Directive between regulatory competition and harmonization will lead to more efficient marketplaces remains to be seen. Certainly, the adoption by the majority of Member States of Article 9 suggests the latter.

${ }^{100}$ Vermeulen, Erik, The Evolution of Legal Business Forms in Europe and the United States (Kluwer Law International, 2003).

101 Report of the High Level Group of Company Law Experts on Issues Related to Takeover Bids, p.22-23. 
Finally, it should be acknowledged that a new concept in EU company law was introduced into the regulatory competition debate in the Directive reciprocity. Article 12(3) allows Member States "to exempt companies which apply" the Articles "if they become the subject of an offer launched by a company which does not apply the same Articles as they do" or a company controlled by such a company. To do so, however, Article 12(5) provides that they need the authorisation of their shareholders at a meeting granted no more than 18 months before the bid. The concept of reciprocity seeks to encourage companies to move to a more liberal regime voluntarily by allowing them the benefit of such a regime where they are the offeror in a takeover bid. It is also notable that the provision was introduced in the context of concerns that the Directive would not create a level playing field between the EU and the United States. It was felt that the Directive would restrict EU companies defending themselves against bids in circumstances where their United States counterparts might not be so limited. ${ }^{102}$ The inclusion of a reciprocity provision runs contrary to the idea that the location or openness to takeover of the offeror is irrelevant and that what should be considered is the location of the offeree. It is argued that reciprocity in takeovers unduly restricts the group of potential offerors to listed companies that are themselves open to hostile bids creating a "fortress Europe" vista and that it reduces the potential benefits of contestable control. ${ }^{103}$ From a theoretical perspective, this limitation is in conflict with the declared aim of protecting the minority shareholders of the offeree. As the empirical evidence suggests that multiple offerors are associated with higher premiums for offeree shareholders, reciprocity is likely to penalise the minority shareholders the Directive seeks to protect in circumstances where it not essential in addressing fairness concerns. In addition, it may be difficult to reconcile this provision with the freedom of

\footnotetext{
${ }^{102}$ Ironically, a convincing argument can be made that the reciprocity provision does not apply to companies from third countries. It could be said that such companies are not in a position to "apply" the same Articles and are thus not caught. An alternative view, and one which the Commission appears to take is that each offeror must be examined on a case-by-case basis to determine whether its own articles of association allow defensive actions or break-through. This rather than the state of incorporation is the relevant determinant of the applicability of Art 12(3).
}

${ }^{103}$ Becht M, “Reciprocity in Takeovers”ECGI - Law Working Paper No 14/2003. 
establishment and free movement of capital under EU law which do not impose any condition on the party wishing to enjoy rights under national company laws other than having the registered office or central administration in a Member State. ${ }^{104}$ In allowing national discrimination, it may also be contrary to the "Most Favoured Nation" principle. The majority of Member States including Ireland and the UK have chosen not to adopt this Article. What is likely, however, is that the first company in a Member State allowing it that seeks to take advantage of it in the context of a hostile bid will be the subject of legal challenge in the European Court of Justice.

\section{CONCLUSION}

Commissioner Bolkestein criticised the final draft of the Directive stating that he was not going to "[pretend] that the version of the Directive agreed today represents a step forward for EU competitiveness or for the integration of EU capital markets". ${ }^{105}$ The Chairman of the London Panel Peter Scott was equally negative stating that the Directive "is hardly a triumph for harmonisation since the contentious areas remain a matter for Member States to decide for themselves." Whether this could have been avoided is a moot point and as noted above benefits may well be derived from the ensuing regulatory competition. The Directive has also been seen to be the source of a number of new problems for Member States already in possession of the minimum standards. For the United Kingdom and Ireland, the Directive brings little in the form of additional safeguards or benefits to an already robust and effective system. The UK Government and the London Panel have expressly stated that the Directive will not yield any significant improvement to the principles or methods by which takeovers and mergers are conducted in the United Kingdom under the City Code. ${ }^{106}$ The UK Government also recognised that the Directive

${ }^{104}$ Winter J "EU Company Law at the Crossroads" at p.12 in Reforming Company and Takeover Law in Europe (Ferrarrini,G Hopt, K Winter J and Wymeersch E (eds) (Oxford University Press, 2004) pp 18-19.

${ }^{105}$ Press Release MEMO/03/245.

${ }^{106}$ London Takeover Panel, 2004 Annual Report , p. 8. 
might give rise to "an increased risk of litigation within the bid process, which could have the effect of delaying or frustrating a takeover bid and hindering the opportunity for shareholders to decide upon its merits." ${ }^{107}$ It is difficult to argue that his unequal exchange can result from an efficient regulatory approach. While this might seem at first glance merely one State's problem, the prominence of the UK securities market and takeover market make this a more significant general concern. Supervisory authorities also face new challenges in interpreting certain of the Directive's more opaque provisions. As the paper has shown, in many cases this will lead to uncertainty, delays in timetables and increased litigation. Finally, the Directive can also be criticized for its failure to tackle certain issues which though dismissed as corporate governance matters have a real impact on the likelihood of bids being made and accepted.

On a more positive note, the Directive might be viewed as a step forward through laying down minimum standards for takeover regulation and applying many of the core values of the UK system at the EU level. ${ }^{108}$ It might be said "to put a floor to the race to the bottom". ${ }^{109}$ The UK Government acknowledged that it opened up the prospect of "improved shareholder protection and access to capital markets across Europe and a potential stimulus for more transparent corporate governance structures with extended shareholder involvement." 110 If implemented in accordance with its own General Principles, it could encourage cross-border takeover

${ }^{107}$ DTI, Company Law Implementation of the European Directive on Takeover Bids, A Consultative Document (January 2005) para 1.8.

${ }^{108}$ Patricia Hewitt, Secretary of State, Foreword DTI, Company Law Implementation of the European Directive on Takeover Bids, A Consultative Document (January 2005).

109 Hertig G and McCahery J “Compny and Takeover Law Reforms in Europe: Misguided Harmonisation Efforts or Regulatory Competition?” ECGI Law Working Paper No. 12/2003.

${ }^{110}$ DTI, Company Law Implementation of the European Directive on Takeover Bids, A Consultative Document (January 2005) para1.9 
activity with consequential improvements in corporate management. ${ }^{111}$ This clearly would be in the public interest. For new accession States, perhaps it could be argued that the Directive gives guidance and provides a useful structure on which to build national takeover regulatory systems appropriate for the EU market. However, it should be noted that a Directive might not have been necessary to provide this. For example, both Ireland and Austria successfully introduced national takeover regulations based very heavily on the City Code and with the advice of the London Panel. Enriques cites this as a general complaint against EU company law - that often when it has introduced new rules, it has done so with respect to issues on which Member States would have most probably legislated even in the absence of an EC mandate.

${ }^{111}$ DTI Partial Regulatory Impact Assessment (2005) at [10]. 